\title{
Changing representations of organized crime in the Italian press
}

Anna Di Ronco (Ghent University) \& Anita Lavorgna (University of Southampton) (accepted for publication in Trends in Organized Crime on February 27, 2016)

\begin{abstract}
Organized crime has long captured the attention of media, with books, movies, television, and the press offering different representations of what organized crime is. These representations tend to vary in different countries according to the specific coverage and reporting preferences of local media. The ways in which organized crime is framed by the media is of great importance, as mediated images of organized crime may have powerful effects on both the general public and policy-makers. The narrative presented, however, might be distorted and not fully correspond to the notion of organized crime as framed by academic communities. Particularly in the Italian scenario, scholarly definitions and narratives around organized crime have evolved and have been refined meaningfully over the years, presenting a complex, multi-layered, and diversified criminal panorama. Several studies have recently addressed press representations of Italian organized crime in the foreign press. However, the way in which the Italian press has represented the changing rhetoric on organized crime has so far been under-investigated. This research presents the results of a longitudinal media analysis of a selection of Italian newspapers, which aims to inspect the ways in which the press has represented the threats posed by organized crime over time.
\end{abstract}

\section{Changing representations of organized crime in the Italian press}

\section{Introduction}

Organized crime (henceforth: OC) has long captured the attention of the media. Books, movies, television, and the press in many countries have throughout the years offered different representations of what OC is, how law enforcement responds to it, and what are its latest trends. The ways in which the notion of $\mathrm{OC}$ is framed by the media is of great importance, given that the various perceptions and narratives presented may have powerful effects on both the general public and on policy-makers. Even more importantly, an inaccurate use of the OC rhetoric may badly influence the public perception of important criminal 
phenomena and even the political debate, which, in turn, may have repercussions in the measures adopted to fight the phenomenon (Fijnaut and Paoli 2004; Young and Allum 2012).

In the Italian scenario, the notion of OC has long been used and debated at many levels, including by the media and academia. Scholarly definitions and narratives around OC have evolved and been refined meaningfully over the years (see, among others, Santino 2006; Bianchini and Sicurella 2007; Paoli 2007; Lavorgna and Sergi 2014a; Savona 2015), presenting a complex, multi-layered, and diversified criminal panorama. While mafia groups are still in the spotlight, practitioners and experts agree that the nature of OC in Italy is much more varied (Sergi 2015: 666). However, current academic views on OC and of how it is fought may not fully correspond to the images that are conveyed through the media, if we consider that simplification, individualism, and binary oppositions are among the common features of media representation of crime (Jewkes 2015).

The aims of this article are twofold. First, it will inspect the ways in which OC has been represented in a selection of Italian newspapers over time, which shall then be compared against the backdrop of the literature on media representations of OC. Second, it will assess whether press representations of OC in Italy correspond to the dominant academic views on the phenomenon.

\section{Different representations of organized crime: the state of the academic research}

\section{Different types of organized crime groups in Italy}

The way Italian OC has evolved over the years and the effectiveness of the law enforcement responses that have been launched against it have both been the subject of much academic interest and writing. Italian scholars have broadly used both historical and socio-legal perspectives in the attempt to boil down what OC is, and the different types of OC groups that are thought to be operating in Italy. For instance, Lavorgna and Sergi (2014 a, b) have recently identified four main types of OC groups operating in Italy, which exploit different social opportunity structures for their criminal activities: mafia-like groups (as identified by the law in art. 416bis of the Italian Criminal Code), migrated mafia groups (mafia groups that have moved away from their traditional territory), mixed criminal networks (criminal groups mainly involved in trafficking activities), and "simple" criminal organizations (as identified in art. 416 of the Criminal Code). 
Numerous studies have been published, especially over the last three decades, with a particular focus on the major Southern Italian mafia groups (the infamous Sicilian Cosa Nostra, as well as the Neapolitan Camorra and the Calabrian 'Ndrangheta) (see, for instance, Arlacchi 1983; Gambetta, 1993; Paoli 2003; Lupo 2004; Allum 2006; Gratteri and Nicaso 2006). These "traditional", mafia-type forms of Italian OC, are described as social powers: among other characteristics, they are deeply embedded in the territory, interwoven with the political and professional elites, and often rely on extortion, intimidation, and corruption as their methods.

Besides these traditional groups, more recent scholarship has increasingly recognized the presence of "new" (both Italian and foreign) types of OC groups, that typically make use of sophisticated instruments to carry out their criminal activities, ranging from new types of investments to the use of innovative techniques (Becucci 2013; Harja 2013; Lavorgna and Sergi 2014b).

In light of the expansion of the "new" OC groups, some authors have questioned the resilience of more traditional criminal groups, such as Cosa Nostra and the 'Ndrangheta. In 2007, for instance, Paoli underlined the successes that the law enforcement responses targeting traditional Italian mafias had had since the 1990s, going as far as seriously undermining their traditional criminal capital (for the successful fight against the Sicilian mafia, see also Fiandaca and Lupo 2014). However, this interpretation contrasts with the more recent academic view, which has underlined the "conversion of the 'mafia extortionist' into the 'mafia entrepreneur'" (Savona 2015), as well as with the view of the major Italian institutional actors. For instance, the newly elected President of the Italian Republic, Sergio Mattarella, and the President of the Court of Appeal of Milan, Giovanni Canzio, have recently painted a picture of mafia-type OC as a current (and undefeated) threat in Italy. ${ }^{1}$ The presence of OC groups, moreover, seems not to be geographically constrained to the southern regions of the country, but rather to have also "colonized" and been "transplanted in" (Varese 2006; Lavorgna et al. 2013: 268) the northern (and richer) areas, as well as abroad. As regards to Italy, the Mafia Presence Index (MPI) developed in Savona and Riccardi (2015) confirms the strong mafia presence in traditional southern regions (Puglia, Calabria, Campania, and Sicilia) and reveals a strong mafia presence in certain areas of north-western and central Italy, particularly Lazio, Liguria, Piemonte, Basilicata, and Lombardia (Savona 2015).

\footnotetext{
1See http://www.quirinale.it/elementi/Continua.aspx?tipo=Discorso\&key=3 and http://www.corteappello.milano.it/documentazione/D_5614.pdf.
} 
Apart from the presence of mafia-type and migrated mafia groups, "mixed criminal networks" (Lavorgna and Sergi 2014a) are another prominent type of OC type present in Italy, which is characterized by the actual crime committed, typically a profit-driven crime, rather than by the characteristics and the structure of the group. This type of OC tends to operate at the margins of society and their opportunistic presence in certain territories is generally linked to trafficking activities. These criminal networks are sometimes made up of homogenous ethnic groups operating in Italy (Paoli 2007), but often these networks are formed by different ethnicities (Lavorgna et al. 2013).

Finally, any type of criminal association, which occurs when at least three persons join together with the aim of committing an indefinite program of felonies (delitti) if they have a permanent and structured internal organization, is a form of OC (what has been called as a "simple criminal organization" by Lavorgna and Sergi 2014a).

From this literature review, OC emerges as a multifaceted and complex phenomenon in Italy, and a conceptual distinction among its different manifestations is necessary, at the very least, to bring clarity to the discussion. Also, this brief overview shows that while traditional mafias (conceptualized as a sub-group of OC) are still largely depicted in terms of social prestige and political influence, especially in their territories of origin, recent studies tend to describe various types of OC manifestations as opportunistic criminal enterprises, and tend to focus on the profit-making scope of their activities.

\section{Media representations of organized crime}

Mediated images of crime and deviance may be distorted or exaggerated. According to von Lampe (2001), in the media as well as in the public discourse of many countries, the definition of OC has historically coincided with (foreign and) ethnically homogeneous criminal groups - an image which has been thought to fit particularly well with the Italian mafia-type organizations (see also Paoli 2003). In line with the Alien Conspiracy theory (Potter 1994; Antonopoulos 2009), for a long time the Italian southern-type criminal associations have, in fact, been identified as the prototype of OC groups in the public discourses of other countries (Paoli 2003; Fijnaut and Paoli 2004; Bonanno 2010; Pruss 2014). This is in contrast to the often broad definitions of OC incorporated in the relevant legal texts (Fijnaut and Paoli 2004). In a recent study, Sarno (2014) found that the label of the Sicilian mafia and of other southern Italian criminal organizations were used in the German, 
Dutch, and Spanish press to generally refer to OC groups, which have been regarded as a "foreign" problem (or a problem belonging to Italy) - an image that does not match the capacities of the mafias abroad to infiltrate the legitimate business sectors, as identified in academic research (Campana 2013; Neubacher 2013). The content analysis performed by Pruss (2014) on the German press led to similar findings: the press tended to represent OC on a n ethnic basis. The label OC, moreover, has sometimes been used to exaggerate the magnitude and extent of a criminal phenomenon in order to draw the attention of the public on a specific "hot" topic and to receive extra resources or power to fight a certain criminal phenomenon (van Duyne 2004; Levi 2008).

Mediated images of $\mathrm{OC}$ also play a role in shaping public perceptions of this specific criminal phenomenon (Woodiwiss and Hobbs 2009; Young and Allum 2012; Savona 2013; Sarno 2014), which is hardly covered by other sources of information (Hall et al. 1978). This seems to be particularly the case for the press. As explained by Allum (2013: 59) in her analysis of the media (and, more generally, of the public) discourse on OC in the UK, "newspapers continuously feed, shape, influence, project, programme the collective picture which a society has of a phenomenon". Such societal perceptions seem to vary according to 'the 'type' of organized crime involved and to the 'where', which means in which country the perception is perceived" (Savona 2013: 7).

While several works have dealt with the intriguing relationship between crime and the media, and an increasing number of studies are taking into consideration the media construction of the OC narrative, there is a gap in the literature as regards to the coverage of news of different types of OC groups by the Italian press. The present study seeks to further this path of inquiry by offering an updated analysis of the Italian press coverage of OC news, and by assessing the extent to which the narrative used is in line with the state of theacademic discourse on the topic.

\section{Methodology: data collection and analysis}

In order to analyze how the Italian press represents OC over time, this study focuses on newspaper articles published in Italy between January 1, 2000 and December 31, 2014. Newspaper articles, compared to other types of news media, allow longitudinal analyses of a certain issue to be conducted in an effective and efficient way (Mawby and Gisby 2009; Sarno 2014). The dates were chosen to capture articles over a period of time sufficient to take into 
consideration possible changes in the public perception of the issue. Particularly, we decided to start our analysis in January 2000, (almost) one year preceding the signing of the UN Convention on Transnational Organized Crime (which was signed in Palermo in December 2000), because we expected several news items on OC to be published around that date and an increase in the attention paid to the issue. Since the keyword search was run in the database in the first months of 2015, it took into account the month of December 2014 as a consistent end date. The time frame (14 years) is in line with what has been used in comparable studies (Young and Allum 2012; Pruss 2014; Sarno 2014).

Consistent with previous research in the field (Young and Allum 2012; Pruss 2014; Sarno 2014), articles were extracted from the database Lexis Nexis Academic. In previous studies, this database was praised as useful for press analyses as it provides full text access and allows searches by time frame, language, and type of source. Trying to keep the search as comprehensive as possible, the following syntax was chosen for the keyword search: mafia OR mafios! OR "crimin! w/5 organizzat!" OR "cosa w/5 nostra" OR ndrangheta OR camorr! OR clan OR "associazione w/5 delinquere" 2 . The search was then entered on the basis of the following criteria: time frame (01/01/2000-31/12/2014); language (Italian); type of source (newspaper). Articles were organized by source order and duplicate options were excluded "if high similarity" was to be found. A total of 421 press items were identified. As already underlined by Weaver and Bimber (2008) among others, news aggregation databases such as Lexis Nexis suffer from major limitations as they do not necessarily constitute archives of the whole content of news appearing, because of the exclusion of major wire services and major newspapers. This might limit the accuracy of a study looking at the news distribution of a particular subject. Also, as already noted in Sarno (2014: 336), the newspapers included in the Lexis Nexis database are not necessarily those with the highest-circulation, which might limit the extent to which the resulting sample reflects an actual influence on the public opinion. It would therefore be interesting to repeat the study by selecting newspapers on the basis of their

\footnotetext{
24. The fact that four of the seven search terms are mafia centered (as they refer to in general to the mafia, and in particular to Cosa Nostra, the "Ndrangheta, and the Camorra) should not be regarded as biasing towards "mafia" the identification of media articles. Rather, the choice of the keywords accounts for all four types of organized crime operating in Italy, as recently described in the socio-legal analysis done by Lavorgna and Sergi (2014a): in fact, "crimin! w/5 organizzat!" and "associazione w/5 delinquere" are deemed broad enough to cover media reporting of mixed criminal networks and "simple" criminal organizations. Also, the authors decided to look singularly for the three main mafias to reflect the fact that nowadays in Italian culture they are consistently represented as specific phenomena with their own singular identity in both journalistic (Limes 2014) and academic (Dickie 2014) discourse. As a consequence, this choice is part of the authors' attempt to be as comprehensive as possible in the source selection.
} 
circulation rates. Also, considering how the ubiquitous presence of social media is having a huge impact on how crime news are reported and circulated (Jeweks, 2015), future research might carry out a similar analysis on data retrieved by some of these highly interactive platforms. Despite these limitations, however, Lexis Nexis Academic was chosen as a proper news aggregator because of its powerful search capability and extensive international (and, for the purpose of our paper, Italian) coverage (Center for Research Libraries 2013). Furthermore, since the news aggregator used is consistent with previous research in the field, it was considered adequate for the scope of this study and for maintaining our methodology as close as possible to the one used in previous studies, in this way facilitating the comparative analysis of the findings.

NVivo, a data analysis software package that allows one to manage and arrange unstructured information, was used to systematically organize and analyze the data sampled from the newspapers. To develop a coding scheme that reflected our research questions, we began by reading a selection of 50 news items (10 percent of the total) to identify key themes emerging from the sources. After this reading, we used NVivo to categorize the relevant passages in the text with 7 main categories or content codes (or "nodes"). They are "when", "speaker" (i.e., the person who speaks, directly or indirectly, in the newspaper article), "OC group", "where", “crime", "response", and "other" (i.e., analyses data and additional information regarding the socio-cultural context, characteristics, and evolution of OC). Subcategories or sub-codes (or, in the language of NVivo, "child nodes", which are usually defined as concepts that inherently belong to the main parent node and that are organized in a hierarchical structure) were also identified for the more complex nodes (who, what, problem, solution, and other). Any node and child node was linked to a reference only once per article. NVivo allowed an iterative process, with new child nodes (and "grandchildren nodes" in two cases) being added or merged as the analysis proceeded. A total of 132 discrete categories were identified (see Appendix A for details).

In the effort to investigate our research question with both breadth and depth, we decided to employ a mixed method. First, we used NVivo to obtain descriptive statistics of the different nodes, child nodes, and grandchildren nodes. Particularly, the number of references (that is, the number of selections within our sources that have been coded with any node) provided us with insights into how the press represented OC. Second, the nodes and their subcategories were used to guide and assist the qualitative part of the content analysis: after using 
open coding (Glaser and Strauss 1967) for the nodes construction, theoretical coding (Glaser and Strauss 1967) was used to organize the articles around two emerging narratives, the first one focusing on cultural views of mafia-type organized crime, and the second one on their economic activities and more recent developments. The results are reported in the following sections.

\section{Results}

\section{Descriptive statistics}

When

The number of newspaper articles covering the topic of OC is rather scarce in the time period stretching from 2000 to 2008, covering less than 14 percent of the total number of articles considered (see Appendix A for details). From 2009 onwards, however, the number of relevant articles started to progressively increase, reaching its highest number in 2013 (78). The different coverage of the topic of OC in the press over the years, however, may have to do with the database Lexis Nexis Academic, which may not have continuously indexed the selected newspapers over time. As a consequence, although the numbers suggest that there has been increasing coverage of news regarding OC over time (this is so, for example, if we focus on the articles of the single newspaper most covered in the database, that is $L a$ Stampa $),{ }^{3}$ we cannot draw any general conclusion on this point.

\section{Speaker}

Unsurprisingly, in the news, the actors that are primarily given a voice are law enforcement officers (in about 39 percent of the news) and national and local policy makers (about 22 percent). The actors whose voices are mostly present in the news are indeed public prosecutors, which appear in 54 articles. These are followed by the Direzione Investigativa Antimafia, the Direzione Nazionale Antimafia, and the Direzioni Distrettuali Antimafia

\footnotetext{
${ }^{3{ }^{\circledR}}$ The highest number of retrieved newspaper articles were published by La Stampa (129), followed by Il Resto del Carlino (83), Il Corriere della Sera (80), Il Giorno (75), La Nazione (39), Italia Oggi (6), Milano Finanza (5), La Gazzetta dello Sport (3), and Marketing Oggi (1). Until 2009, the newspaper La Stampa was responsible for most of the OC-related news. Starting from the year 2009, the topic of OC has been increasingly covered also in the other press titles. This has probably to do with the database Lexis Nexis Academic, which may have included articles from the other newspapers only since more recent years. Other potential problems related to the database lay in the inclusion of newspapers that have a regional focus (such as Milano Finanza and Il Resto del Carlino), which might have led to an overrepresentation of the views on OC dominant in some central and northern regions.
} 
(which coordinate anti-mafia investigations at different geographical levels) (36 references), judges (25), local law enforcement bodies (the Police and the Carabinieri) (19), and prefects (14). Members of the national government, of the parliament (and, within the latter, of the relevant parliamentary commissions addressing the issue of OC), and of regional and local administrations also are substantially present in the news of the press, as they were given a voice in 85 articles.

Research centers and academics studying the phenomenon of OC (33 references, 8,7 percent), representatives of civil society (27,7 percent), and people in the media industry ( 24 , equal to 6.3 percent) appear relatively less often in the news. Other categories of people having their voices less covered in and by the news (all less than 4 percent of the total news) are: industry and category associations (15), OC members (13), pentiti and justice collaborators (9), and priests and bishops of the Christian Catholic faith (8). Little room is given in the news to the victims of OC and their relatives, whose voices appear in the press in only 6 references.

Overall, as has already been stressed by Levi (2008) and Pruss (2015), also in the Italian press' representation of $\mathrm{OC}$ there is an over-reliance on police sources, which are overrepresented compared with other relevant actors. The research community, on the other hand, is relatively underrepresented as a source of information (which is in line with Pruss 2015).

\section{OC group}

The traditional Italian mafias (the Calabrian 'Ndrangheta, the Neapolitan Camorra, ${ }^{4}$ and the Sicilian mafia) are by far the most represented in the news media, with 291 (equal to 38 percent of the total news), 226 (30 percent), and 128 references (about 17 percent) respectively (while all other groups account individually for less than 4 percent). While the Sicilian mafia received constant attention over the years, the Camorra and the 'Ndrangheta received increasing attention starting in 2009. Only in the last couple of years have references been found covering local manifestations of mafia-type OC (such as the Casamonica Clan based near Rome). Other traditional manifestations of Italian OC (Banda della Magliana) and

\footnotetext{
${ }^{4}$ Unlike the other traditional Italian mafias, the Camorra's organizational structure is more horizontal, with several mafia-like clans (such as the infamous Casalesi clan) based in Campania and acting independently of each other (Paoli 2007). In this analysis, however, the several clans have been grouped together under the umbrella term "Camorra" as it would have otherwise been impossible to keep them consistently separated given the lack of precisions in most news articles in the press with regards to this aspect of the organization.
} 
mafia-type OC (Sacra Corona Unita ${ }^{5}$, which have so far received relatively limited academic attention, have been mentioned in the newspapers (in 5 and 32 articles respectively). However, these groups were generally considered en passant, listed among other OC groups, without receiving specific attention. It is interesting to note that the sources considered emphasized cases of alliances and collaborations among the traditional mafias, to the point that the results of these alliances received specific names in the articles, such as "Fifth mafia" (12 references) or "Ndracamostra" (2). So far, to the authors' knowledge, this issue has received no academic attention, while the term "fifth mafia" has been used by Chiavari (2011) to identify a different phenomenon - that is, the expansion of the 'Ndrangheta in the North of Italy and particularly in Lombardy.

Overall, the newspapers analyzed demonstrate that $\mathrm{OC}$ is almost completely conceived in terms of (domestic) mafia organizations, and that what happens in terms of OC/mafia activities outside of Italy receives almost no attention. It is surprising how very little attention is given to the transnational dimension of OC. While the notion of Transnational OC, albeit criticized (van Duyne 2011; van Duyne and Nelemans 2012), remains a concept at the forefront of academic interest (or at least an issue academics have to confront) (Carrapico et al. 2015; Antonopolous 2015), only 3 articles focused on the issue. However, it should also be acknowledged that these specific results might have been affected by the search terms used to identify the relevant newspaper articles (see above, in the methodology section).

Moderate attention was dedicated to ethnic groups (for a total of 37 references, about 5 percent of the total number of news articles). These groups are mostly deemed to be involved in "transit crimes" (Kleemans 2007) and in the exploitation of prostitution. In most references there is general mention of "alien organizations", or a superficial use of the term mafia (such as in "Eastern mafia", "Nigerian mafia", "Albanese mafia") without examining in any depth the characteristics of the groups. Hence, relatively scarce attention has been drawn to realities that have been quite broadly treated in the academic literature. However, we do not exclude the possibility (rather, we expect) that newspapers deal much more with ethnic criminality than we found in our sample (Cardella et al. 2008; Capuano 2013). A possible explanation for the relatively scarce number of references is that ethnic groups might not have been generally framed as being tied to $\mathrm{OC}$; instead being associated with other forms of street/high-volume

\footnotetext{
54s explained in Paoli (2007), contrary to media accounts, the "Sacra Corona Unita" no longer exists as a single viable organization, but there is rather a multiplicity of criminal groups, gangs, and white-collar criminal networks operating in the Apulia region, so that it would be more correct to refer to these groups as "Apulian Organized Crime".
} 
crimes. This seems to indicate that the Italian press behaves differently than the German, Dutch, and Spanish press, where OC tends to be framed in ethnic terms (Sarno 2014; Pruss 2015).

Gangs ("bande") are not reported as a significant problem, with only 4 references found (all after 2011).

\section{Where}

The presence of $\mathrm{OC}$ in the press has mostly been associated with the regions situated in the north of the country ( 49 percent of the total number of news articles). The data shows that the highest number of articles referring to OC pertain to Lombardia, the region where Milan is situated (101 references, equal to about 23 percent of the total). Other northern regions where OC has been reported in the news are: Emilia Romagna (59), Piemonte (26), and Liguria (14). Among the regions in the center of the country, which have been identified in the news as the locus of OC, there are Lazio (43), and Toscana (30). In the southern and insular parts of the country, the regions where the presence of OC was mostly reported, are Calabria (44), Campania (37), and Sicilia (17), followed by Puglia (9), which are the original homelands of the traditional forms of OC (i.e., of 'Ndrangheta, Camorra, the Sicilian mafia, and Sacra Corona Unita).

In the process of coding, it was noted that while most of the news published until 2009 associated the presence of $\mathrm{OC}$ with the southern regions, in more recent years the focus has been on the northern regions. This finding is consistent with what has been put forth in the academic research, which has emphasized the substantial presence of OC in the central and northern regions of the country (Varese 2006; Lavorgna et al. 2013; Calderoni 2011, 2014). It should also be noted that only a limited number of news articles (14, equal to only 3,2 percent of the total number of news articles) covered the presence of OC in a foreign country.

\section{Crimes}

Trafficking in drugs, with 94 references (almost 14 percent of the total number of news articles on OC), is the main criminal activity covered by the press. The focus is mostly on the 'Ndrangheta, with many news articles being about the trafficking of cocaine from South America. Money laundering follows with 75 references (about 11 percent). Most news articles deal with real estate investments in both Italy and other EU countries, while only a limited 
number of news articles are on $\mathrm{OC}$ involvement in the finance sector. There is also massive attention paid to the involvement of traditional mafias in public tenders and licenses (61 references) and in politics and public administration (52 references), which demonstrates the press' interest in and attention to a representation of $\mathrm{OC}$ as a systemic condition, focusing on the concentration of power resulting from an apparent alliance between criminals and political and economic elites (while ignoring the parallel narrative of the mafia as an underworld government) (von Lampe 2008).

Usury and extortion (58), intimidation and attacks (40), and murder/attempted murder (37) follow in number, which is not surprising considering the "telegenic" characteristics of these crimes. The involvement of traditional mafias in the construction sector accounted for 34 references, while a significant number of references (33) linked OC to the commercial sector and local/global tourism and nightlife, these latter especially after 2008. Gambling, mafia association (including external association) charges, ${ }^{6}$ and weapons and explosives follow, all with 26 references. It is worth noting that, regarding weapons and explosives, the focus is not on their trafficking/trade, but rather on possession or usage. Trafficking in arms is only mentioned en passant in lists with other "typical" OC activities, but there are no references to specific cases. The 24 references to environmental crimes concern almost completely cases of illegal waste disposal. A bit surprising is the relatively scarce attention (20 references) paid towards corrupt practices (corruption and economic disturbance), which have long been considered key tools used by OC (Arsovska 2011), although they have been recently problematized (Lavorgna and Sergi 2014b). As regards (the exploitation of) prostitution, the 17 references focus on the involvement of ethnic groups and the Camorra. Theft and robbery (often referred to as "organized property crime", see for instance Savona and Riccardi 2015) have been reported in only 16 references. Fraud (including EU fraud) and counterfeiting (and here the focus is on Chinese groups) follow with 13 and 12 references respectively.

Only 9 references linked human trafficking and smuggling (considered together in the analysis, as it was often not clear in the press what phenomenon they were referring to) to $\mathrm{OC}$, which is very surprising given that these issues are generally presented as core examples of (transnational) OC in academia (von Lampe 2012) and in the political context (consider the 2000 United Nations Convention against Transnational Organized Crime and its Protocols).

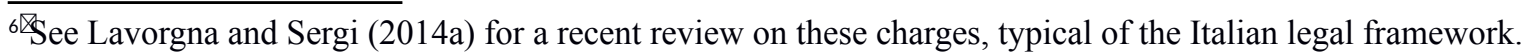


Similarly, it was surprising to find only 5 references linking OC to cigarette smuggling and to the football sector respectively, and 4 to the gangmaster system. ${ }^{7}$ Relative attention (compared to the little attention paid by academia) was also dedicated to the mafias' involvement in the food industry ( 8 references) - especially in relation to a supposed agreement between the traditional mafias to form a sort of "criminal cartel" to manage the distribution of certain foods from Sicily and Calabria onwards - and to rural crime (3) - which is reported by the media as an important source of profits for mafias.

Overall, the picture that emerges is that there is an extreme heterogeneity of activities in which OC is deemed to be involved, as evidenced by the fact that almost no criminal activity exceeds 10 percent of the press coverage. In some of these cases, however, there is a generic reference to $\mathrm{OC}$ but no reference to one specific group.

\section{Responses}

Most of the provided solutions rely on the description of the repressive actions and the sanctions to be imposed on OC members, which accounts for about 59 percent of cases. For example, the arrest of OC members is indicated as the response in 70 articles, whereas the seizure of the profits of $\mathrm{OC}$ is identified in 58 of them. The successful accomplishment of police investigations follows, with 31 references. The conviction of OC members is seen as a solution in 12 items, whereas in 5 it is associated with the special regime of the 41 bis. Other solutions include the adoption of other types of sanctions for individuals or organizations involved in the criminal activities of the OC group (24), which may encompass the suspension from a profession for professionals, the disqualification from a public function for public officials and politicians, the expulsion from category associations or from public tenders for enterprises, and so forth.

Also, solutions focused on (social and situational) crime prevention were given substantial coverage in the news (29 percent). For example, in 43 articles the mobilization of civil society against $\mathrm{OC}$ is indicated as a solution. Furthermore, the reporting of OC to the police (15), the enhancing of administrative monitoring in the area of public procurements (14), the establishment of new specialized investigative units, and the introduction of new powers for the existing investigative or police bodies (14) are identified as crucial for the sorting out of the problems posed by OC. By contrast, only in a limited number of references

\footnotetext{
${ }^{78}$ Caporalato (gangmaster system) is the activity of unlawful intermediation between employers and workers, which results in the exploitation of illegal work.
} 
(10) did the solution coincide with the reform of the substantive and/or procedural criminal law provisions, which are considered to be pivotal to enhancing the chances of arresting, prosecuting, and sentencing OC members.

\section{Other}

Information regarding mafias' lifestyles, rituals, ideologies, modus operandi, as well as on the historical and recent evolution of the traditional mafias received a lot of attention overall from the press, with a total of 105 references (or 49 percent of the total). The articles considered under this node are very heterogeneous, ranging from articles explaining methods of intimidation and techniques to communicate from inside prison to a few analyses of affiliation ceremonies and how mafia groups changed over time. The focus is only on traditional mafias (and specifically on the 'Ndrangheta and the Camorra) rather than on other OC groups. It is once again interesting to note that several news articles paid attention to the pax mafiosa among the traditional mafias and to their agreements in splitting up businesses and areas of influence, which is something that has been overlooked in academia.

A total of 19 references deal with the promotion of books and/or public events and meetings. Also in this case, they all focus on traditional Italian mafias.

With the exception of Germany (after the "Duisburg massacre" in 2007), very limited attention was dedicated to mafias' expansion (and presence) abroad, and to the responses to OC in other countries. Only 13 references (mostly on the 'Ndrangheta involvement in drug trafficking) offer some additional information on or explanations of the international dimension of $\mathrm{OC} / \mathrm{mafias}$.

In 23 articles there was information and/or comments on the "social context" in which mafias proliferate. In this domain, especially when presenting cases of connivance and regarding the code of silence, beyond articles on the traditional Italian mafias there were also a few articles referring to the "Chinese mafia".

A total of 14 articles provided brief analyses and/or data on the Italian criminal (and administrative) justice system, including on the confiscation of criminal assets; 12 references were on the presence of dissent in anti-mafia policies and approaches (for instance, on the disagreement between an anti-mafia prosecutor and a member of the government). 
Attention was dedicated in the press also to anti-mafia heroes (those who accept risky situations to counter a mafioso system) and martyrs (such as journalists that were killed or heavily intimidated because of their work), for a total of 9 references.

A few but interesting analyses were presented on the relationship between mafias and religion and women and mafias, particularly since 2008 ( 6 and 5 references respectively).

\section{Qualitative analysis and discussion}

Two main narratives describing the three main mafias were identified, which were recurrent in the press articles analyzed: (1) mafia as a social power, and (2) mafia as an enterprise. While the first one appears in the news throughout all the years considered, the second one is only frequent and recurrent in the news published in the last 6-year-period (i.e., from 2009 to 2014).

\section{Mafia as a social power}

Since the first year analyzed (2000) and consistently over the years, the press has constantly offered a view of OC in line with the traditional, almost stereotyped, narratives about the mafia. As already anticipated, press articles focus particularly on the three notorious traditional Italian mafia organizations - the Sicilian Cosa Nostra, the Neapolitan Camorra, and the Calabrian 'Ndrangheta. This is not surprising, as the Italian approach to OC has always traditionally been an approach to the mafia (Mitsilegas 2003; Paoli 2003) with the two concepts de facto overlapping. The focus on the mafia as a main target of intervention can also be found in the anti-mafia legislation, which over the years was broadened to enhance the investigative capacities of law-enforcement agencies to persecute groups that were initially not taken into consideration (see Lavorgna and Sergi, 2014a for an overview). Consequently, in the Italian press, OC is mostly depicted by journalists, law enforcement officers, national policy makers, civil society, writers, and movie directors as the mafia and as a domestic problem.

The three mafias are presented in a way that stresses their peculiar cultural connotations: $\mathrm{OC}$ is something more, something different from other forms of crime. For instance, consider the following quote:

Everything, in the 'Ndrangheta, is a symbol. If the organization was merely a criminal one, it would have been easily defeated, over the last century, by the police forces. But it 
always had links and networks with the powerful. It flaunts the Madonna and uses religious exhibition to gain social legitimacy. What is new, then, always needs what is old (Il Corriere della Sera, 14 July, 2014).

Here the conventional leitmotiv of mafias using religion to gain legitimacy in its social context is very clear. Mafias (the 'Ndrangheta in this particular case) are characterized as entities deeply rooted in the territory, while, at the same time, being deeply connected with the elites.

Also, when the press deals with the traditional mafia homelands, references to mafias' traditional way of living are often emphasized, the language evoking the presence of an immutable world, where OC has always played a role.

An ancient world, almost medieval, ruthless, violent, $[\ldots]$ that resisted modernization and still was able to adapt itself to globalization by focusing on the big international crime markets, first and foremost on drugs [...] Morabito, from the old guard, an illiterate peasant from another era, was captured in a farmhouse in the hinterland of the hinterland of Reggio Calabria (La Stampa, 23 February, 2004).

It is not surprising that, in terms of responses, the focus is mainly on repressive responses and on some types of community-level, long term crime prevention responses, such as civil mobilization and education.

Especially since 2009, there has been increasing attention paid in the press to the processes of expansion of the traditional southern mafias toward other Italian regions, similarly to the increasing attention in academia to the processes of colonization and delocalization in recent years (Varese 2006; Lavorgna et al. 2013). When mafias are on the move, the press language tends to change: mafias are something that arrived at a certain point in time, and are non-endogenous to the territory.

The big criminality arrives in this peaceful provence in the middle of the '1980s [...] Some bosses, or even just picciotti and cumparielli [i.e., OC members at the bottom of the hierarchy], were sent to the soggiorno obbligato [i.e., forced relocation] towards municipalities that were extremely peaceful, where the most serious possible crime events were burglaries (La Nazione, 30 December, 2011).

While academic analyses problematize the presence of OC more, with an increasing emphasis on the blending with the upperworld, what prevails in the press is the polarized logic of "us vs. them" in order to emphasize an "ontological" difference between OC and the 
legitimate word. This view disregards the fact that, beyond and in addition to the mafias' associates at all levels of the Italian crime scene, we also find people belonging to the mainstream population with no other criminal connections (Paoli 2007). ${ }^{8}$ This rhetoric is not surprising. First, the use of binary oppositions is common in crime stories, where polarized and simplified frameworks of understanding tend to be offered (Jewkes 2015: 53). Second, as has been stressed by Sarno (2014), the identification of OC with (Italian) mafias has always been instrumental in separating OC from mainstream society, since the Alien Conspiracy theory was born in the US. Consider, for instance the following example:

[...] It is surprising to find that the first sentence for mafia association in all the Emilia Romagna is from June 2008. The false myth of the happy isle resisted long enough and it was time that someone started looking deeper. We have been long witnessing [...] people going around our streets with their pockets full of dirty money [...] The mafiosi [...] are dodgy persons, who care their own business and silently penetrate among us [...] And if this is true for the mafias, it should be true also for the other mafia, even more silent and invisible, named Chinese mafia (Il Resto del Carlino, 3 July 2011, emphasis added).

Theoretically, this view of OC seems to be supported by the Alien Conspiracy theory when it comes to non-traditional mafia territories such as Emilia Romagna. In contrast, the situation in the traditional mafias' homelands seem to be explained through the Differential Association frame (Sutherland, 1973), which focuses on the idea that behavioral traits are passed on from one generation to another that share the same set of values and beliefs. Italian mafias, even in a peculiar way, are presented by the media as a specific type of ethnic criminals, as outsiders that are responsible for serious crimes. Even in the more rare cases where the press deals with non-Italian OC, OC is generally presented as mafia-type ethnically homogeneous groups. It is interesting to note that this interpretation of OC mafias offered by the Italian press suggests that the Italian press frames the issue of OC differently from other European media. Pruss' (2015) analysis of the German press, for instance, identified various journalistic frames based on theoretical approaches from within criminological paradigms and (largely sustained by the law-enforcement sources) showed that the rational choice frame was prevalent there, followed by the Alien Conspiracy frame.

\section{Mafia as enterprise}

\footnotetext{
8 Only in the 23 references identified with the sub-node "social context" was the narrative different. The focus was on the fact that the mafioso attitude is common also outside mafia families, that the search for profit links the underworld and the upperworld, and that citizens sometimes cheer for mafia bosses.
} 
Progressively, from 2009 onwards, the discourse in the press regarding OC has increasingly described OC groups as criminal enterprises. By relying mainly on the words of public prosecutors, police officers, and members of investigative units, OC has been described as a profit-driven organization concerned with the identification of favorable opportunities for the commission of crimes and with the maximization of its profits. An example is provided by the news that reported a change in the relations between OC groups over the years. Criminal organizations are said to no longer be fighting with each other in order to obtain a monopoly over a criminal market or control over a territory. Rather, as anticipated above, they are described as allied partners who seal economic agreements ("old vendettas have been set aside [...] under the name of business" Il Giorno, 20 June 2009). Agreements are concluded between $\mathrm{OC}$ groups not only to ensure a peaceful co-existence in a territory, but also to share legal (such as public tenders and procurements) and illegal markets (such as the drug market).

In line with recent academic views on the phenomenon (Campana 2011, Lavorgna and Sergi 2014a), OC groups (and especially the 'Ndrangheta) are also described as focusing on new types of economic activities, which were usually neglected in earlier years. This is particularly evident in the news that speaks about the presence of OC groups in the richer regions of the central and of the north of the country: the thriving economic opportunities present in these areas are seen as the main motivation for OC members to move their criminal targets and activities from the southern regions of the country. This is exemplified in the fragment below, where a public prosecutor is quoted as saying:

This is a rich territory, and therefore this [the presence of OC.] is a real problem, as it is in all Europe. In certain production sectors, such as the earthmoving, the construction and the logistic, organized crime becomes more competitive at the level of the price, succeeding to penetrate the local economic system. The contexts of Modena and Reggio Emilia [two cities in Emilia Romagna] have proven to be more vulnerable ( Il Resto del Carlino, 1 May 2011).

In their pursuit of profits and economic gain, OC groups are also said to no longer rely on their military arsenal and on their methods of intimidation based on violence, threats, and extortion. Rather, they use techniques that are "more subtle" (Italia Oggi, 10 November 2005), as they rest on the collusion with local politicians, public bureaucrats, professionals, and companies. Because of the utilization of new types of techniques that allow them to permeate the licit economy, criminal organizations have also changed their image, which has 
been adjusted to the socio-cultural characteristics of the central and northern territories. This new image rather differs from the one that criminal organizations usually have (or are thought to have) in the southern regions, as exemplified in the following fragment:

You see in Scampia [a city near Naples] you recognize the mafiosi by their luxurious life and by their behavior. In Milan, no. They are more careful, and invest high amounts [of money] in public contracts hiding their real job (Il Giorno, 1 March 2014).

Special attention is given in the news to the development of "Ndrangheta, which is described as the most successful and profitable OC group and often defined in business terms-for example, as a "business" (Il Giorno, 20 June 2009) or as a "Malavita holding" (La Stampa, 29 January 2004). The secret of the success of the Calabrian mafia lies in its ability to re-adjust and adapt its activities very quickly according to the set of risks and opportunities it faces on the different territories (it "changes skin", Il Giorno, 20 June 2009, and La Stampa, 13 April 2011), despite maintaining its traditional (family-based) structure. An example of such adjustments is offered in the fragment below:

The 'Ndrangheta changes, and also Milan - its entrepreneurial and economic feud. The rules are adapted until the limit of the genetic mutation (Corriere della Sera, 5 Oct. 2014).

The responses that have been identified in the press to counteract economic-driven OC groups not only refer to the successful pursuance of investigations, which lead to the arrest of OC members and to the seizure of their criminal assets. They are also centered on raising the awareness of (mainly) entrepreneurs and civil society regarding the harmful consequences of OC, with a view to increasing the number of reports filed to the police.

The attention given to the economic component of criminal organizations has also led the press to identify other types of (criminal) organizations, which have been labeled as being a mafia in light of their aim to pursue an economic return through the commission of criminal acts, rather than because of the adoption of the mafioso method. This is especially evident in the news covering the recent scandal called "Mafia Capitale" by the media, which refers to the criminal activities carried out in Rome by an organized (criminal) group with the aim of gaining profits from the public sector through a net of collusions between the business, the administrative and political worlds with the involvement of traditional OC groups. As emerges from the snippet below, although such an organization is seen to differ from the 
traditional mafia groups, its economic-driven interests and its threatening methods seem to "justify" the application of the label "mafia": 9

Carminati [the alleged leader of this criminal group] and partners have started up a mafia enterprise that has used corruption, social relations [...], and the threat of violence to lay its hands on pieces of the public expenditure. [...] The term clan is narrow. I would say a mafia enterprise that is able to make huge profits by taking over substantial parts of the public expenditures. [...] What the territory, the neighborhood, the city represent for the traditional mafia, was the public expenditure for this criminal enterprise (La Stampa, 13 Dec. 2014).

The media narrative depicting "mafia" (in its broad sense) as an economic enterprise can be explained through the framework of the rational choice perspective: OC groups are said by the press to organize their economic activities in light of the criminal opportunities present in the different geographical areas and in the uneven (licit and illicit) markets present there. To reduce the risk of being caught and to avoid losing the profits of their activities, moreover, "mafia" groups are said to rationally mutate and adapt to the new set of conditions and situational opportunities that are found in the "new" territories. This view, therefore, is in line with the prevalent frame in the German press, as identified by Pruss (2015).

\section{Conclusions}

Representations of $\mathrm{OC}$ in the Italian press have been dominated by the voices of law enforcement officers and policy makers, which have mostly focused on the description of the traditional Italian OC groups (Cosa Nostra, Camorra, 'Ndrangheta), rather than on foreign OC groups or on groups with an international dimension. The main responses to the threats posed by $\mathrm{OC}$ are repressive and rely, for example, on the successful pursuance of investigations, leading to the arrest of OC members, and to the seizure of their criminal profits. Other types of responses are based on social prevention, which rests, for example, on activities that aim to raise the awareness of civil society, and on situational prevention, which refers to activities that seek to prevent the occurrence of crime committed by mafia groups. Furthermore, although in the past OC (interpreted as mafia) was seen by the press as being mainly concentrated in the southern regions of the country, from 2009 onwards the focus shifted to the northern regions.

\footnotetext{
9"In the specific case of "Mafia Capitale" the public prosecutors filed an allegation according to article 416 bis of the Italian criminal code (which punishes mafia-type OC).
} 
Two recurring narratives emerged during the quantitative part of the content analysis. The first one, which could frequently be seen during all the years considered, describes OC as a sub-culture with specific habits, rituals, and modus operandi. This representation of (traditional) OC persists, and could also be seen in the last 6-year-period, when the presence of OC is known to be widespread in the central and northern regions (where an "ontological" cultural difference with respect to the nature of such organizations is emphasized). From 2009 onwards, however, this representation in the press starts to coexist (and be partially offered as a contrast) with a more economic-driven view of the phenomenon: traditional criminal organizations are said to change their original characteristics to better adapt to the new "conquered" territories and maximize their profits. They are, therefore, no longer described only as social powers; rather, they are also identified as criminal businesses, which have changed their rules in order to camouflage their existence in the new areas and therefore better infiltrate the legal economy. In this second narrative, (organized) criminal groups with an economic vocation (which, however, do not share the characteristics of mafia-like groups as set in art.416bis) have also been included in the definition of "mafia". While the first narrative appears to be in line with the views on OC that are dominant also in the foreign press, the second narrative is more specific to the discourse in the Italian press and should be kept in mind for comparative purposes.

Relating these representations in the press back to the academic views on the phenomenon of $\mathrm{OC}$, it is possible to see a similarity: both discourses describe OC groups as evolving towards more sophisticated forms of economic organization and expanding to new territories. However, while scholarly research has associated this economic characteristic with heterogeneous types of OC, the press has almost exclusively focused on traditional forms of Italian OC. Even when the press "stretches" the notion of mafia to cover other types of OC groups, it does so to include "domestic" cases of organized criminal activity, rather than foreign groups or groups with a transnational dimension. Hence, press representations of OC reflect only a part of the multifaceted academic debate on the developments of OC. Also, in contrast with academia, the press tends not to link the OC narrative with certain complex criminal activities such as human trafficking and smuggling.

\section{Appendix A}




\section{Codes and sub-codes}

\begin{tabular}{|c|c|c|}
\hline Child node & Grandchild node & References (=articles) \\
\hline \multicolumn{3}{|l|}{ Node: WHEN } \\
\hline 2013 & & 78 \\
\hline 2010 & & 68 \\
\hline 2012 & & 64 \\
\hline 2014 & & 57 \\
\hline 2011 & & 57 \\
\hline 2009 & & 40 \\
\hline 2008 & & 10 \\
\hline 2004 & & 9 \\
\hline 2005 & & 8 \\
\hline 2001 & & 8 \\
\hline 2007 & & 7 \\
\hline 2006 & & 5 \\
\hline 2003 & & 5 \\
\hline 2002 & & 4 \\
\hline 2000 & & 1 \\
\hline \multicolumn{3}{|l|}{ Node: SPEAKER } \\
\hline \multirow[t]{6}{*}{ LAW ENFORCEMENT } & & 148 \\
\hline & Public prosecutors & 54 \\
\hline & DIA, DNA, DDA & 36 \\
\hline & Judges & 25 \\
\hline & Police and Carabinieri & 19 \\
\hline & Prefects & 14 \\
\hline $\begin{array}{l}\text { NATIONAL/ REGIONAL/LOCAL } \\
\text { ADMINISTRATORS AND POLICY MAKERS }\end{array}$ & & 85 \\
\hline RESEARCH CENTERS AND ACADEMICS & & 33 \\
\hline CIVIL SOCIETY \& STUDENTS & & 27 \\
\hline $\begin{array}{l}\text { JOURNALISTS, WRITERS, AND MOVIE } \\
\text { DIRECTORS }\end{array}$ & & 24 \\
\hline $\begin{array}{l}\text { INDUSTRY AND CATEGORY ASSOCIATIONS } \\
\text { (e.g., Confindustraia, Confcommercio, CGIL, } \\
\text { Cisl, etc.) }\end{array}$ & & 15 \\
\hline OC MEMBERS & & 13 \\
\hline PENTITI AND JUSTICE COLLABORATORS & & 9 \\
\hline PRIESTS AND BISHOPS & & 8 \\
\hline VICTIMS \& THEIR RELATIVES & & 6 \\
\hline OTHER & & 13 \\
\hline
\end{tabular}




\begin{tabular}{|c|c|c|}
\hline 'NDRANGHETA & & 291 \\
\hline CAMORRA & & 226 \\
\hline SICILIAN MAFIA & & 128 \\
\hline \multirow[t]{7}{*}{ ETHNIC GROUPS } & & 37 \\
\hline & Chinese & 17 \\
\hline & Albanian & 12 \\
\hline & Russian & 9 \\
\hline & Romanian & 7 \\
\hline & Nigerian & 6 \\
\hline & Others & 17 \\
\hline SACRA CORONA UNITA & & 32 \\
\hline \multirow[t]{12}{*}{ OTHER } & & 42 \\
\hline & Alliance ("Fifth mafia" & 12 \\
\hline & "Mafia Capitale" & 6 \\
\hline & Banda della Magliana & 5 \\
\hline & Casamonica Clan & 4 \\
\hline & Gangs & 4 \\
\hline & Magnis Brothers & 3 \\
\hline & Transnational Organized Crime & 3 \\
\hline & 'ndracamostra & 2 \\
\hline & Mixed groups & 1 \\
\hline & New mafias & 1 \\
\hline & Stidda & 1 \\
\hline \multicolumn{3}{|l|}{ Node: WHERE } \\
\hline \multirow[t]{8}{*}{ NORTH } & & 212 \\
\hline & Lombardia & 101 \\
\hline & Emilia Romagna & 59 \\
\hline & Piemonte & 26 \\
\hline & Liguria & 14 \\
\hline & Veneto & 6 \\
\hline & North (not specified) & 5 \\
\hline & Valle d'Aosta & 1 \\
\hline \multirow[t]{5}{*}{ CENTER } & & 84 \\
\hline & Lazio & 43 \\
\hline & Toscana & 30 \\
\hline & Umbria & 7 \\
\hline & Marche & 4 \\
\hline \multirow[t]{2}{*}{ SOUTH \& INSULAR } & & 121 \\
\hline & Calabria & 44 \\
\hline
\end{tabular}




\begin{tabular}{|c|c|c|}
\hline & Campania & 37 \\
\hline & Sicilia & 17 \\
\hline & Puglia & 9 \\
\hline & Abruzzo & 7 \\
\hline & $\begin{array}{l}\text { South (or Mezzogiorno, not } \\
\text { specified) }\end{array}$ & 3 \\
\hline & Basilicata & 2 \\
\hline & Sardegna & 2 \\
\hline FOREIGN COUNTRY & & 14 \\
\hline \multicolumn{3}{|l|}{ Node: CRIMES } \\
\hline DRUGS & & 94 \\
\hline MONEY LAUNDERING (incl. real estate) & & 75 \\
\hline PUBLIC TENDERS \& LICENCES & & 61 \\
\hline USURY \& EXTORTION & & 58 \\
\hline POLITICS \& PUBLIC ADMINISTRATION & & 52 \\
\hline INTIMIDATION \& ATTACKS & & 40 \\
\hline MURDER \& ATTEMPTED MURDER & & 37 \\
\hline CONSTRUCTION SECTOR & & 34 \\
\hline COMMERCE, TOURISM, \& NIGHTLIFE & & 33 \\
\hline GAMBLING & & 26 \\
\hline $\begin{array}{l}\text { MAFIA ASSOCIATION (incl. external } \\
\text { participation) charge }\end{array}$ & & 26 \\
\hline WEAPONS \& EXPLOSIVES & & 26 \\
\hline ENVIRONMENTAL CRIME & & 23 \\
\hline CORRUPT PRACTICES & & 20 \\
\hline \multirow[t]{14}{*}{ OTHER- } & & 105 \\
\hline & Prostitution & 17 \\
\hline & Theft \& robbery & 16 \\
\hline & Fraud & 13 \\
\hline & Counterfeiting & 12 \\
\hline & Human trafficking and smuggling & 9 \\
\hline & Food industry & 8 \\
\hline & Cigarettes & 5 \\
\hline & Football & 5 \\
\hline & Gangmaster system \& illegal work & 4 \\
\hline & Abscond & 3 \\
\hline & Diamonds & 3 \\
\hline & Rural crime & 3 \\
\hline & ATM skimming & 2 \\
\hline
\end{tabular}




\begin{tabular}{|c|c|c|}
\hline & Used clothes & 2 \\
\hline & Boatyard & 1 \\
\hline & Criminal brokerage & 1 \\
\hline & Media & 1 \\
\hline \multicolumn{3}{|l|}{ Node: RESPONSES } \\
\hline \multirow[t]{7}{*}{ REPRESSIVE RESPONSES } & & 200 \\
\hline & Arrest & 70 \\
\hline & Seizure & 58 \\
\hline & Investigations & 31 \\
\hline & $\begin{array}{l}\text { Other sanctions (e.g., } \\
\text { disqualification or exclusion from a } \\
\text { public tender, etc.) }\end{array}$ & 24 \\
\hline & Conviction & 12 \\
\hline & 41 bis & 5 \\
\hline \multirow[t]{7}{*}{ PREVENTIVE RESPONSES } & & 98 \\
\hline & Civil mobilization and education & 43 \\
\hline & Filing a police report & 15 \\
\hline & Monitoring of public tenders & 14 \\
\hline & New investigation teams or powers & 14 \\
\hline & $\begin{array}{l}\text { Cooperation between law } \\
\text { enforcement }\end{array}$ & 8 \\
\hline & New resources and financing & 3 \\
\hline \multirow[t]{7}{*}{ OTHER } & & 40 \\
\hline & Criminal law reforms & 10 \\
\hline & Dissolution of a municipal council & 7 \\
\hline & $\begin{array}{l}\text { Changes in the political world or } \\
\text { political reforms }\end{array}$ & 6 \\
\hline & Re-utilization of seized OC assets & 5 \\
\hline & $\begin{array}{l}\text { Discharge/ } \\
\text { acquittal }\end{array}$ & 4 \\
\hline & Other & 8 \\
\hline \multicolumn{3}{|l|}{ Node: OTHER } \\
\hline $\begin{array}{l}\text { MAFIAS'LIFESTYLE, MODUS OPERANDI, } \\
\text { AND EVOLUTION }\end{array}$ & & 105 \\
\hline $\begin{array}{l}\text { SOCIAL CONTEXT, CONNIVENCE, AND } \\
\text { CODE OF SILENCE }\end{array}$ & & 23 \\
\hline $\begin{array}{l}\text { PROMOTION OF BOOKS AND PUBLIC } \\
\text { EVENTS ON MAFIA-TYPE OC }\end{array}$ & & 19 \\
\hline $\begin{array}{l}\text { CRIMINAL JUSTICE (legal framework, stats and } \\
\text { problems) }\end{array}$ & & 14 \\
\hline INTERNATIONAL DIMENSION & & 13 \\
\hline
\end{tabular}




\begin{tabular}{|l|l|l|}
\hline OTHER & & 40 \\
\hline & Dissent in antimafia & 12 \\
\hline & Antimafia martyrs and heroes & 9 \\
\hline & Women \& mafias & 6 \\
\hline & Mafias \& religion & 5 \\
\hline & Pentiti and justice collaborators & 5 \\
\hline & Camorra \& music & 2 \\
\hline
\end{tabular}

Ethical approval: This article does not contain any studies with human participants or animals performed by any of the authors.

\section{References}

Allum F (2006) Camorristi, Politicians, and Businessmen: The Transformation of Organized Crime in Post-war Naples. Northern Universities Press, Leeds

Allum F (2013) Godfathers, dark glasses, and pasta: discussing British perceptions of Italian Mafias. Sicurezza Scienze Sociali. I(3): 52-68

Antonopoulos GA (2009) Are the others coming? Evidence on alien conspiracy from three illegal markets in Greece. Crime Law Soc Chang 52(5): 475-493

Antonopoulos GA (2015) Tackling Myths in Order to Tackle Transnational Organised Crime, RUS I Newsbrief, available online at: https://www.rusi.org/publications/newsbrief/ref:A54C63BE2C0D65/\#.Vd3g584selg

Arlacchi P (1983) La mafia imprenditrice. L'etica mafiosa e lo spirito del capitalismo. Il Mulino, Bologna

Arsovska J (2011) Conceptualizing and studying organized crime in a global context: possible? Indispensible? Superfluous? In: Smith CJ, Zhang SX, Barberet R (eds) Handbook of international criminology. Routledge, New York, pp 211-225

Becucci S (2013) La criminalità organizzata cinese in Italia. Sicurezza e Scienze Sociali 3 : 94-116

Bianchini E, Sicurella S (2007) Il crimine organizzato in Italia: analisi evolutiva. Riv Criminol Vittimol Sicurez 1: 111-127

Buonanno M (2010) Da la piovra a l'ultimo padrino. Vent'anni di storie di mafia nella fiction italiana. Problemi dell'Informazione 3: 289-311

Calderoni F (2011) Where is the mafia in Italy? Measuring the presence of the mafia across Italian provinces. Glob Crime 12(1): 41-69 
Calderoni F (2014) Measuring the presence of the mafias in Italy. In: Caneppele S, Calderoni F (eds) Organized crime, corruption and crime prevention. Essays in honor of Ernesto U. Savona. Springer International Publishing, London, pp 239-249

Campana P (2011) Eavesdropping on the Mob: The functional diversification of the mafia across territories. European Journal of Criminology 8(3): 213-228.

Campana P (2013) Understanding then responding to Italian organized crime operations across territories. Policing 7(3): 316-325

Capuano RG (2013) La percezione della criminalità nigeriana in Italia: un confronto tra le fonti accademiche e le rappresentazioni giornalistiche. Sicurezza Scienze Sociali 3:117-137

Cardella C, Macaluso M, Tumminelli G (2008) Rappresentazioni delle organizzazioni criminali straniere in Italia. In: Dino A, Pepino L (eds) Sistemi criminali e metodo mafioso. FrancoAngeli, Milan, pp 126-140

Carrapico H, Irrera D, Tuman B (2015) Introduction - transnational organised crime and terrorism: different peas, same pod. In: Carrapico H, Irrera D, Tuman B (eds) Criminals and terrorists in partnership: Unholy alliance. Routledge, London

Center for Research Libraries (2013) Broadcast News Transcripts in Academic News Databases, as reported in available online at: https://www.crl.edu/sites/default/files/d6/images/tg/Broadcast\%20Transcripts\%20Review $\% 202013 \% 20$ final.pdf

Chiavari M (2011) La quinta mafia: come e perché la mafia al nord oggi è fatta anche da uomini del nord. Ponte alle Grazie, Milan

Dickie J (2014) Mafia Republic: Italy's Criminal Curse. Cosa Nostra, 'Ndrangheta and Camorra from 1946 to the Present. Sceptre, London

Fiandaca G, Lupo S (2014) La mafia non ha vinto. Laterza, Bari

Fijnaut C, Paoli L (2004) Organized crime in Europe: concepts, patterns, and control policies in the EU and beyond. Springer, Dordrecht

Gambetta D (1993) The Sicilian Mafia: The Business of Private Protection. Harvard University Press. Cambridge, MA

Glaser B, Strauss A (1967) The discovery of grounded theory: Strategies for qualitative research. Aldine, Chicago

Gratteri N, Nicaso A (2006) Fratelli di sangue: la 'ndrangheta tra arretratezza e modernità. Pellegrini Editore, Siena

Hall S, Critcher C, Jefferson T, Clarke J, Roberts B (1978) Policing the crisis. Mugging, the state, and law and order. Macmillan Press LTD, Basingstoke

Harja A (2013) Mafia romena in Italia. Sicurezza e Scienze Sociali 3: 138-160

Jewkes Y (2015) Media and crime. Sage, London 
Kleemans E (2007) Organized crime, transit crime, and racketeering. Crime Justice 35(1): $163-215$

Lavorgna A, Lombardo R, Sergi A (2013) Organized crime in three regions: comparing the Veneto, Liverpool, and Chicago. Trends Organ Crime 16(3): 265-285

Lavorgna A, Sergi A (2014a) Types of organised crime in Italy. The multifaceted spectrum of Italian criminal associations and their different attitudes in the financial crisis and in the use of Internet technologies. Int J Law Crime Justice 42(1): 16-32

Lavorgna A, Sergi A (2014b) Different manifestations of organised crime and corruption in Italy: a socio-legal analysis. In: van Duyne PC, Harvey J, Antonopoulos G, von Lampe K, Maljević A, Markovska A (eds) Corruption, greed and crime-money. Sleaze and shady economy in Europe and beyond. Wolf Legal Publishers, Oisterwijk, pp 139-162

Levi M (2008) White-collar, organised and cyber crimes in the media: some contrasts and similarities. Crime Law Soc Chang 49(5): 365-377

Limes (2014) “Quel che resta dell'Italia”. November.

Lupo S (2004) Storia della mafia. La criminalità organizzata in Sicilia dalle origini ai giorni nostri. Donzelli Editore, Roma

Mawby RC, Gisby W (2009) Crime, media and moral panic in an expanding European Union. Howard J Crim Justice 48(1): 37-51

Mitsilegas V (2003) From national to global, from empirical to legal: the ambivalent concept of transnational organized crime. In: Beare ME (ed) Critical reflections on transnational organized crime, money laundering and corruption. University of Toronto Press, Toronto

Neubacher F (2013) Italian mafias and how they are perceived in Germany. Sicurezza Scienze Sociali a. I(3): 30-52

Paoli L (2003) Mafia brotherhoods: organized crime, Italian style. Oxford University, Oxford

Paoli L (2007) Mafia and organised crime in Italy: the unacknowledged successes of law enforcement. West European Politics 30(4): 854-880

Potter GW (1994) Criminal organizations: vice, racketeering and politics in an American city. Waveland, Prospect Heights

Pruss S (2014) Media's portrayal of ethnic organised crime in Germany and its implications. European Rev Organised Crime 1(2): 97-118

Santino U (2006) Dalla mafia alle mafie. Scienze sociali e crimine organizzato. Soveria Mannelli, Rubbettino

Sarno F (2014) Italian mafias in Europe: between perception and reality. A comparison of press articles in Spain, Germany and the Netherlands. Trends Organ Crime 17(4): 313-341

Savona EU (2013) Editorial. Sicurezza Scienze Sociali a. I(3): 7-10 
Savona EU (2015) The businesses of Italian mafias. European Journal Criminal Policy Research. DOI: 10.1007/s10610-014-9261-7

Savona EU, Riccardi M (2015) From illegal markets to legitimate businesses: the portfolio of organised crime in Europe. Final Report of Project OCP - Organised Crime Portfolio. Transcrime, Milan

Sergi A (2015) Divergent mind-sets, convergent policies: Policing models against organized crime in Italy and in England within international frameworks. European Journal of Criminology 12(6): 658-680.

Sutherland, EH (1973) Development of the theory. In: Schuessler K (ed) On analyzing crime, University of Chicago Press, Chicago, pp 13-29

van Duyne PC (2004) The creation of a threat image: media, policy making and organised crime. In: van Duyne PC, Jager M, von Lampe K, Newell JL (eds) Threats and phantoms of organised crime, corruption and terrorism. Wolf Legal Publishers, Oisterwijk, pp 21-50

van Duyne PC (2011) (Transnational) Organised crime, laundering and the congregation of the gullible. Tilburg University, available online at: http://www.cross-bordercrime.net/index.php?page $=$ Free $\% 20$ Downloads

van Duyne PC, Nelemans MDH (2012) Transnational organized crime: thinking in and out of Plato's cave. In: Allum F, Gilmour S (eds) Routledge handbook of transnational organized crime. Routledge, London, pp 36-51

Varese F (2006) How mafias migrate: the case of the 'Ndrangheta in northern Italy. Law Soc Rev 40: 411-444

von Lampe K (2001) Not a process of enlightenment: the conceptual history of organised crime in Germany and the United States of America. Forum Crime Soc 1(2): 99-116

von Lampe K (2008) Organized crime in Europe: conceptions and realities. Policing (2)1: 717

von Lampe K (2012) Transnational organized crime and challenges for future research. Crime Law Soc Chang 58(2): 179-194

Weaver DA, Bimber B (2008) Finding news stories: a comparison of searches using Lexisnexis and google news. J Mass Comm Q 85(3): 515-530

Woodiwiss M, Hobbs D (2009) Organised evil and the Atlantic alliance: moral panics and the rhetoric of organized crime policing in America and Britain. Br J Criminol 49(1): 106-128

Young AB and Allum F (2012) A comparative study of British and German press articles on "organised crime" (1999-2009). Crime Law Soc Chang 58(2): 139-157 